\title{
Perjuangan Gerakan Buruh Tidak Sekedar Upah Melacak Perkembangan Isu Gerakan Buruh di Indonesia Pasca Reformasi
}

\author{
Muhammad Zuhdan
}

\begin{abstract}
The purpose of this paper is to track issues championed by the labor movement after the reform. The first thesis of this paper behold issue championed labor movement is not merely a matter of wage increases. This paper focus on championed issue by the labor movement in the post-reformation Indonesia. The reasons for selecting this theme is to expand the public's view on the issue of labor which has always been synonymous with wage when the labor movement has long roots and a tradition of thought that labor issues are always dialectical and dynamic with the changing socio-political structure. The results of this study indicate that the issue of the labor movement in the post-reformation Indonesia no longer dwell on the issue of wage increase alone but develops progressively in the direction of political issues that is identical to the New Left movement, ranging from labor issues Go Politics, anti-neoliberalism, gender, human rights, democracy, citizenship, public policy, etc.
\end{abstract}

\section{Keywords:}

issue; labour movement; post reformation

\begin{abstract}
Abstrak
Tujuan penulisan ini adalah untuk melacak isu-isu yang diperjuangkan oleh gerakan buruh pasca reformasi. Tesis pertama dari tulisan ini bahwasanya isu yang diperjuangkan gerakan buruh tidak semata-mata masalah kenaikan upah. Fokus masalah yang diangkat oleh tulisan ini yaitu isu-isu yang diperjuangkan oleh gerakan buruh di Indonesia pasca reformasi. Alasan pemilihan tema ini adalah untuk memperluas pandangan publik atas isu perburuhan yang selama ini selalu diidentikan dengan masalah upah padahal gerakan buruh memiliki akar tradisi pemikiran yang panjang dan isu perburuhan selalu dialektis dan dinamis dengan perubahan struktur sosial politik. Hasil dari penelitian ini menunjukan bahwa isu gerakan buruh di Indonesia pasca reformasi tidak lagi berkutat pada isu kenaikan upah saja tetapi berkembang progresiv ke arah isu-isu politis yang identik dengan gerakan Kiri Baru, mulai dari isu buruh Go Politic, anti neoliberalisme, gender, HAM, demokrasi, kewarganegaraan, kebijakan publik, dan sebagainya.
\end{abstract}

\section{Kata Kunci:}

isu; gerakan buruh ; pasca reformasi

\footnotetext{
- 'Peneliti di Social Movement Institute (SMI) Yogyakarta Email: mzoehdan@yahoo.com
} 


\section{Pendahuluan}

Kenaikan upah menjadi isu yang selalu melekat ketika terjadi aksi mogok kerja serikat buruh di Indonesia pasca reformasi. Isu ini seolah-olah menjadi isu tunggal yang diperjuangkan kaum buruh ketika aksi mogok, aksi blokade jalan, ataupun aksi demonstrasi. Kata "buruh" dan "upah" seakan-akan melekat satu sama lain antara definisi dan maknanya, berbicara buruh dikonotasikan berbicara tentang upah sehingga pemerintah dan publik sering terjebak dalam kesempitan isu ketika berbicara tentang buruh. ${ }^{1}$ Asumsi tersebut meruncing pada relasi isu kebijakan pemerintah dengan kaum buruh hanya sebatas pada masalah Upah Minimum Provinsi/ Kabupaten (UMP/UMK). Diakui bahwa

\footnotetext{
${ }^{1}$ Kamus Besar Bahasa Indonesia mengartikan kata 'buruh' sebagai orang yang bekerja untuk orang lain dengan mendapat upah. UU 13/2003 tentang Ketenagakerjaan pasal 1 ayat 3 menyebutkan: Pekerja/Buruh adalah setiap orang yang bekerja dengan menerima upah atau imbalan dalam bentuk lain. Sedangkan konsep "buruh" memiliki akar epistemologi yang beragam dan mengalami perdebatan paradigmatik yang luar biasa antara Hegelian versus Marxian. Bagi Hegelian, konsep buruh berkaitan erat dengan kerja-kerja immaterial manusia, dan manusia bekerja atas imaginasi keinginannya sendiri sedangkan Marxian berpendapat bahwa konsep buruh berkaitan dengan kerja-kerja material manusia, dan manusia bekerja bukan karena imaginasi keinginannya sendiri melainkan dibawah kendali kuasa dominasi pemilik alat produksi. Penulis menempatkan konsep buruh dalam kerangka Marxian, karena buruh yang dimaksud penulis adalah sebagaimana Marx konsepkan yaitu manusia yang bekerja untuk memenuhi kebutuhan material mereka dengan menggantungkan pada kaum pemilik alat produksi sedangkan mereka sendiri tidak punya alat produksi kecuali hanya tubuh mereka sendiri sehingga relasi antara pemilik modal dengan buruh bersifat dominatif dan eksploitatif yang mana buruh menjadi objek dominatif dan eksploitatif dari pemilik modal/ alat produksi. Lihat lebih lanjut, Sean Sayers, "The Concept of Labor:Marx and His Critics", dalam Science \& Society, Vol. 71, No. 4, October 2007, 431-454
}

kenaikan upah memang menjadi isu strategis yang diperjuangkan oleh kaum buruh tetapi bukan menjadi isu tunggal dari perjuangan gerakan buruh.

Isu kenaikan upah buruh menjadi memanas tatkala harus berhadapan dengan negara dan pasar. Semasa Orde Baru, Kasus Marsinah menjadi titik hitam bagi sejarah politik Indonesia tatkala buruh harus dijadikan tumbal 'kongkalingkong' antara negara dan pasar. ${ }^{2}$ Marsinah menjadi salah satu saksi bisu kejamnya negara dan pasar dalam membungkam aksi perjuangan kaum buruh di Indonesia tatkala menuntut kenaikan upah sebagai salah satu hak perburuhan. Angkatan Bersenjata Republik Indonesia (ABRI) saat itu menjadi representasi negara dalam merepresi kaum buruh, sedangkan asosiasi pengusaha menjadi representasi pasar untuk menekan pemerintah.

Isu perjuangan kaum buruh semasa Orde Baru tidak hanya semata masalah kenaikan upah tetapi perjuangan hak sipil politik atas eksistensi organisasi mereka. Rezim Orde Baru sangat represif atas eksistensi organisasi serikat buruh. ${ }^{3}$ Mereka tidak hanya dicap sebagai antek-antek Partai Komunis Indonesia (PKI) tetapi juga dianggap sebagai penghambat

\footnotetext{
2 Marsinah, perempuan muda berusia 23 tahun, bekerja sebagai buruh rendahan di perusahaan pabrik arloji PT Catur Putra Surya (CPS) di Porong, Sidoarjo, Jawa Timur. Marsinah ditemukan tewas 5 Mei 1993 dengan tubuh yang penuh luka-hasil otopsi bahwa dia mengalami penyiksaan dan perkosaan. Marsinah mati akibat aksi perjuangannya menuntut kenaikan upah dan jaminan sosial buruh dengan melakukan aksi mogok kerja pada tanggal 3 Mei 1993. Sampai saat ini kasus kematian Marsinah masih menyisakan misteri siapa pelaku utamanya walaupun disinyalir pelakunya adalah konspirasi antara tentara dan pimpinan perusahaan dimana dia bekerja. Kasus Marsinah tercatat di International Labour Organization (ILO), nomor 1773, 20 April 1994, merupakan "pending case" dan pernah menjadi agenda sidang ILO. Lihat lebih lanjut, M.S. Hidajat, Seabad Gerakan Buruh Indonesia, Jakarta : Nuansa Aulia, hlm. 167-178.

3 Hanya satu organisasi buruh yang diijinkan berdiri oleh Orde Baru, yaitu Serikat Pekerja Seluruh Indonesia (SPSI).
} 
pembangunan. ${ }^{4}$ Aksi mereka sering dimaknai sebagai tindakan subversif melawan negara ketimbang dimaknai sebagai realitas politik demokratis. Pemosisian kaum pemodal sebagai mitra pembangunan Orba menjadi ancaman tambahan bagi nasib kaum buruh. Oligarkisme ekonomi yang di-backing kekuatan militer menjadi sebuah struktur politik yang harus dihadapi oleh serikat buruh saat itu. Oleh sebab itu, isu utama yang diperjuangkan kaum buruh semasa Orde Ba ru lebih banyak mengarah pada masalah tuntutan hak sipil dan hak politik, yaitu eksistensi dan independensi politik serikat organisasi kaum buruh.

Setelah rezim Orde Baru tumbang dan kran politik diperlebar, organisasi serikat buruh tumbuh berkembang di Indonesia tetapi tantangannya juga makin komplek. ${ }^{5}$ Gerakan buruh mulai berani melakukan perjuangan politik secara manifest. ${ }^{6}$ Setelah lepas dari kekangan Orde Baru selama hampir 32 tahun, gerakan buruh bangkit lagi dengan memunculkan orientasi dan isu baru agar bisa eksis dalam situasi sosial politik yang baru. Perubahan orientasi dan isu kaum buruh ini mulai nampak tatkala mereka harus berhadapan dengan intervensi pasar yang kian kuat mencengkram negara akibat derasnya laju

\footnotetext{
4 Penataan kembali politik pasca 1965 secara khusus difokuskan untuk menghambat kembali gerakan sayap kiri. Sentral Organisasi Buruh Seluruh Indonesia (SOBSI) sebagai sebuah federasi buruh yang terikat erat dengan Partai Komunis Indonesia menjadi sebuah pelajaran penting bagi rezim Orde Baru untuk tetap "warning" atas eksistensi serikat buruh. Atas dasar itu, gerakan buruh semasa Orde Baru sering diidentikan dengan PKI. Lihat lebih lanjut, Vedi R Hadiz. (2005). Dinamika Kekuasaan: Ekonomi Politik Indonesia PascaSoeharto. Jakarta: LP3ES, hlm. 62.

5 Lihat Jurnal Sosial Demokrasi. Vol. 10, 4, Edisi JanuariMaret 2011.

6 Terbitnya pasal 5 Undang-Undang Nomor 21 tahun 2000 tentang Serikat Pekerja/Serikat Buruh, terdapat kebebasan para buruh untuk membentuk serikat kerja di tiap-tiap unit usaha dengan dukungan sekurang-kurangnya 10 (sepuluh) orang buruh tersebut membuat buruh makin giat melakukan konsolidasi secara manifest untuk membuat serikat-serikat buruh
}

neoliberalisme pasca reformasi. Isu dominan mereka bukan lagi represif negara tetapi lebih mengarah pada tekanan pasar internasional dibawah bendera Multi National Corporation (MNC), World Trade Organization (WTO), dan World Bank. Pasar menjadi musuh nyata gerakan buruh dan pemerintah kian bingung ketika harus mediasi antara kepentingan buruh dengan pengusaha. Pengusaha dan buruh sama-sama membangun kekuatan dan jejaring politik agar kepentingan mereka bisa terakomodir dalam proses pembuatan kebijakan.

Salah satu prestasi politik awal tuntutan buruh pasca reformasi di ranah kebijakan publik yaitu dikeluarkannya Undang-Undang No. 13 tahun 2003 tentang Ketenagakerjaan. Yang cukup menjadi ancaman serius bagi pengusaha dalam undang-undang tersebut adalah tentang sanksi yang akan diberikan oleh negara kepada perusahaan yang mencoba melanggar ketentuan Upah Minimum Provinsi (UMP). Pengusaha yang tidak membayarkan upah sesuai ketentuan UMP dianggap sebagai pelaku kejahatan dengan ancaman sanksi penjara dari satu hingga empat tahun dan denda minimal Rp 100 juta dan maksimal Rp 400 juta. UMP yang ditetapkan merupakan gaji pokok bagi pekerja yang masih belum menikah dan punya masa kerja 0-12 bulan. ${ }^{7}$

Setelah 15 tahun reformasi, gerakan buruh seakan-akan dilihat hanya sebagai kumpulan massa pragmatis yang hanya berjuang menuntut kenaikan upah saja ketimbang gerakan yang punya root ideologi dan platform politik. Asumsi ini akan dicoba dibuktikan oleh tulisan ini dengan berangkat dari pertanyaan dasar, apakah gerakan buruh sekarang sudah pragmatis orientasi isu gerakannya, yaitu hanya sekedar memperjuangkan masalah kenaikan upah ataukah serikat buruh sekarang justru mengembangkan orientasi isu gerakannya

\footnotetext{
7 http://id.wikipedia.org/wiki/Upah_minimum_ regional. (diakses 28 Desember 2013).
} 
yang tidak hanya sekedar perjuangan isu kenaikan upah? Oleh sebab itu, menarik sekali untuk melacak beragam isu yang sebenarnya diperjuangkan oleh gerakan buruh pasca reformasi. Atas dasar itu, tulisan ini akan mengangkat tema tentang isu apa saja yang diperjuangkan gerakan buruh pasca reformasi di Indonesia.

Untuk menjawab tantangan tersebut penulis lebih menggunakan pendekatan kualitatif. Populasi penelitian gerakan buruh di Indonesia, sedangkan sampel penelitiannya adalah gerakan buruh yang berdomisili di Jabotabek dan Surabaya. Para narasumber dipilih berdasarkan purposive sampling yaitu cara memilih para narasumber berdasarkan preferensi kapasitas pengetahuan dan pengalaman ataupun representasi mereka atas topik yang diteliti. Adapun para narasumbernya Obon Tobroni (Wakil Ketua Umum/Komandan Garda Metal) Federasi Serikat Pekerja Metal Indonesia (FSPMI), Jumisih (Ketua Umum Forum Buruh Lintas Pabrik/FBLP Bekasi), Akbar Rewako (perwakilan Konfederasi Kongres Aliansi Serikat Buruh Indonesia/ KASBI dan Sekretaris Bersama Buruh/Sekber Buruh), Jamaludin (Ketua Komite Aksi Jaminan Sosial, Surabaya). Kemudian data-data primer digali dengan wawancara mendalam, Focus Group Discussion, dan observasi. Kemudian, data-data sekunder digali dengan telaah literatur dan dokumentasi. Untuk menggali data yang lebih dalam penulis melakukan live in di lingkungan subyek penelitian. Analis data dilakukan melalui tahap: koleksi, klasifikasi, kategorisasi, kodifikasi, dan interprestasi.

\section{Marxisme Klasik dan Isu Buruh}

Isu aksi gerakan buruh memiliki akar yang kuat dari pemikiran marxist. Melalui Das Capital-nya dan Manifesto Communist-nya Karl Marx menjadi the first conceptor tentang kaum buruh, walaupun Karl Marx sendiri belum pernah memimpin aksi kaum buruh tetapi pada akhir abad ke-19 pemikiran Marx menjadi pedoman ideologis perjuangan kaum buruh. ${ }^{8}$ Dalam tradisi Old Left atau Old Marxist, isu perjuangan buruh pada awalnya hanya seputar masalah hubungan produksi antara kaum pemodal dengan kelas pekerja. Kenaikan upah dan pengurangan waktu jam bekerja menjadi isu yang diperjuangkan oleh kaum buruh. Nilai lebih atas sebuah barang yang berbanding terbalik dengan nilai upah pekerja menjadi isu kritis yang selalu diangkat oleh kaum buruh.

Jika para ahli ekonomi borjuis melihat hubungan antar-benda (pertukaran antarkomoditi), Marx dalam Das Capital-nya memperhatikan hubungan antar-manusia. ${ }^{9}$ Pertukaran komoditi mencerminkan hubungan-hubungan di antara para produser individual yang terjalin melalui pasar. Uang memperlihatkan bahwa hubungan itu menjadi semakin erat, yang tanpa terpisahkan menyatukan seluruh kehidupan ekonomi dari para produser. Modal (kapital) memperlihatkan suatu perkembangan lanjutan dari hubungan ini: tenaga kerja manusia menjadi suatu komoditi.

Para pekerja upahan menjual tenaga kerjanya kepada para pemilik tanah, pemilik pabrik dan alat-alat kerja. Seorang pekerja menggunakan sebagian waktu kerjanya untuk menutup biaya hidupnya dan keluarganya (mendapat upah), sebagian lain waktu kerjanya digunakan tanpa mendapat upah, semata-mata hanya mendatangkan nilai lebih untuk para pemilik modal. Nilai lebih merupakan sumber keuntungan, sumber kemakmuran bagi kelas pemilik modal. ${ }^{10}$ Akibatnya ada eksploitasi

8 Franz Magnis-Suseno. (2013). Dari Mao ke Marcuse: Percikan Filsafat Marxis Pasca-Lenin. Jakarta: Gramedia Pustaka Tama, hlm. 3.

9 Frederick Engel. (2007). Tentang Das Capital. Jakarta: Oey Rennesaince.

Buku aslinya berjudul On Marx's Capital yang ditulis oleh Frederick Engel lalu diterjemahkan ke dalam bahasa Indonesia oleh Oey Hay Djoen.

${ }^{10}$ http://www.marxists.org/indonesia/archive/ lenin/1913/tigasumb.htm. (diakses 30 Desember 2013). 
besar-besaran kaum borjuis (pemilik alat produksi) atas kaum proletar (kelas buruh). Untuk lepas dari ekploitasi kaum borjuis, Marx menganjurkan kepada kaum buruh untuk melakukan sebuah revolusi proletariat. ${ }^{11}$ Dan tradisi pemikiran Old Marxist sangat setuju dengan tesis Marx ini.

Kemudian, relasi negara dan kelas pekerja menurut pandangan Old Marxist ini sangatlah oposan. Definisi negara menurut pandangan Old Marxist hanyalah alat kelas dominan. ${ }^{12}$ Negara juga menjadi sebuah alat pemaksa fisik dari kepentingan kaum borjuis. Negara tidak akan pernah memihak kelas pekerja, karena negara hanyalah sarana produksi kelas borjuis untuk mempertahankan status quo mereka. Lebih lanjut, tradisi pemikiran Old Marxist tidak setuju negara menjadi wadah akhir dari tujuan masyarakat karena tujuan akhir dari sebuah masyarakat adalah masyarakat komunis tanpa kelas. Adanya semangat revolusi proletariat dan anti eksistensi negara tersebut kaum buruh semasa Old Marxist sering memprogapagandakan isu perjuangan kelas, isu kenaikan upah, isu anti eksploitasi, dan isu anti kapitalisme.

Sepeninggal Marx, orangyang meneruskan tradisi pemikiran Old Marxist adalah Vladimir Lenin. Dia mencoba mengembangkan isu kenaikan upah, isu perjuangan kelas, anti ekspolitasi, anti kapitalisme dan revolusi proletariat yang sebelumnya digagas oleh Marx menjadi isu yang lebih terstruktur. Marx awalnya hanya menekankan bangkitnya kesadaran kelas kaum buruh untuk melawan sistem kapitalisme tetapi Lenin mencoba menstrukturisasi kesadaran kelas tersebut dengan membentuk serikat buruh. ${ }^{13}$ Bagi Lenin,

\footnotetext{
${ }^{11}$ http://www.marxists.org/archive/marx/works/ download/pdf/Manifesto.pdf. (diakses 30 Desember 2013).

${ }^{12}$ Ernest Mendel. (2013). Pengantar Marxisme. Yogyakarta: Bintang Nusantara, hlm. 9.

${ }^{13}$ William Ebenstein. (2006). Isme-Isme Yang Mengguncang Dunia. Yogyakarta: Narasi, hlm. 41.
}

buruh akan bisa mengalahkan kapitalisme jika membuat serikat atau partai. Lenin, melalui karyanya What Is To Be Done (1902) menegaskan bahwa kaum pekerja harus membentuk organisasi-organisasi buruh dengan tujuan pokok ekonomi. Organisasi yang bekerja secara terbuka, sah, dan sedapat mungkin menjadi organisasi umum. Serikat pekerja yang telah terbentuk tersebut harus bisa berdampingan dengan perkumpulan-perkumpulan kecil revolusioner profesional.

Dari sini kita bisa melihat perkembangan isu yang digalang oleh kaum buruh dari masa Marx sampai Lenin, isu-isu tersebut yaitu kenaikan upah, perjuangan kelas, pengurangan waktu jam kerja buruh, anti kapitalisme, anti eksploitasi, anti imperialisme, pembentukan serikat atau partai kelas pekerja. Gerakan buruh semasa Marx sampai Lenin sering dikenal dengan Old Labour.

\section{New Left dan Gerakan Buruh}

Pasca Lenin, isu buruh menjadi lebih luas seiring dengan dialektika perkembangan pemikiran marxist. Dialektika pemikiran marxist mengalami dua fase perdebatan internal di kalangan pemikir marxist sendiri. Fase pertama saat perang dunia I dan perang dunia II (awal abad 20) dan fase kedua saat runtuh dan pecahnya Uni Soviet sembari ditandai kemunculan kekuatan neoliberalisme dan kemunduran gerakan buruh (pertengahan abad 20). Kedua fase tersebut membuat para intelektual marxist mengkritik dan mengkaji ulang Marxisme Klasik agar bisa menjawab fenomena politik baru di abad 20. Para tokoh pemikir marxist yang mencoba mengkritik dan mengkaji ulang pemikiran Marxisme Klasik tersebut sering dikenal sebagai pemikir Post Marxist.

Tokoh-tokoh pemikir Post Marxist pada fase pertama seperti Theodor Adorno, Herbeth Marcuse, Max Horkheimer, Antonio Gramsci, George Lukacs, dan Karl Korsch berpendapat bahwa Marxisme Klasik perlu dikritik karena 
gagal menjelaskan terjadinya imperialisme sekaligus gagal menjelaskan terjadinya perkembangan masyarakat kapitalis yang diluar dugaan mengalami percepatan luar biasa di abad 20. ${ }^{14}$ Sedangkan tokoh-tokoh post marxist fase kedua yaitu Habermas, Goran Therborn, Slavoj Zizek, Ernesto Laclau, Chantal Moufe, Alain Badiu, dan sebagainya berpendapat bahwa pemikiran Marxisme Klasik gagal dalam menjelaskan posisi negara ketika terjadi krisis kapitalisme karena negara selama ini dianggap oleh kaum Marxisme Klasik sebagai aktor oposisi tetapi bagi kaum Post Marxist negara justru menjadi aktor yang paling strategis untuk dijadikan alat kaum buruh untuk mengontrol eksploitasi kapitalis dan melalui instrumen negara hak-hak kaum buruh bisa dilindungi secara legal. ${ }^{15}$

Kemudian dalam hal melihat bentuk kekuasaan kapitalisme, Post Marxist mengkritik Marxisme Klasik yang masih melihat bentuk kekuasaan kapitalisme dalam bentuk kekuasaan dominasi melalui alat-alat produksinya dan perangkat represif negara padahal bagi Post Marxis bentuk kekuasaan kapitalisme sudah bertranformasi lebih canggih dan abstrak tetapi bisa mempengaruhi alam bawah sadar sekaligus sikap dan tindakan kaum buruh, bentuk kekuasaan semacam ini disebut sebagai kekuasaan hegemonik. ${ }^{16}$ Awal dan pertengahan abad 20 gerakan buruh mengalami kemunduran dalam pergerakan, tetapi setelah muncul perdebatan di kalangan internal pemikiran Marxist tersebut gerakan buruh

\footnotetext{
${ }^{14}$ David Held. (1980). Introduction to critical theory: Horkheimer to Habermas. University of California Press, hlm. 14.

${ }^{15}$ http://www.rebelion.org/hemeroteca/petras/ english/critique170102.htm. (diakses 7 Mei 2014).

${ }^{16}$ Ernesto Laclau \& Chantal Moufee. (2008). Hegemoni dan Strategi Sosialis: Post Marxisme dan Gerakan Sosial Baru. Yogyakarta: Resist Book.

Lihat juga, Nezar Patria \& Andi Arief. (2009). Antonio Gramsci: Negara \& Hegemoni. Yogyakarta: Pustaka Pelajar.
}

mulai merubah arah orientasi ideologis dan pergerakannya mengingat struktur kekuasaan kapital sudah berubah dan berubah pula isu yang dihadapinya sehingga butuh strategi baru untuk menghadapinya.

Dari hasil dialektika di kalangan Post Marxist tersebut lahirlah pemikiran Kiri Baru. Istilah Kiri Baru atau The New Left diperkenalkan kali pertama dalam majalah The New Left Review (1959) yang dikelola kelompok Post Marxist. Nama tersebut diberikan oleh sosiolog Amerika, C. Wright Mills tahun 1958. Kiri Baru berlawanan dengan Kiri Lama, yaitu partai sosial demokrat di Barat (Kiri Baru) dengan partai-partai komunis (Kiri Lama). Kiri juga dipertentangkan dengan Kanan. Kanan, yaitu mereka yang mempertahankan sistem dengan cara konservatif; dan orang-orang Kanan bisa terdapat dalam kubu kapitalis maupun komunis. Sedangkan Kiri, menurut Mills adalah kritik terhadap struktur aktual masyarakat. Dalam pandangannya, menjadi Kiri berarti melibatkan diri dalam kritik politis, baik dalam hal tuntutan-tuntutan politis maupun program-program. Aspirasi dasar dari gerakan ini adalah counter modernization. Isu-isu yang sering diangkat adalah kritik terhadap konsumerisme, pola hidup borjuis modern, dan demokrasi semu. ${ }^{17}$

Munculnya New Left berpengaruh juga pada perkembangan isu yang diperjuangkan oleh gerakan buruh. Pemikiran New Left secara progresif melahirkan gerakan New Labour. Gerakan New Labour mulai mewacanakan isuisu yang terkait dengan konteks perubahan kondisi struktur masyarakat, yaitu mulai dari isu adaptasi budaya, penerimaan nilai-nilai baru, dan kepemimpinan yang kuat. ${ }^{18}$ Selain isu-isu tersebut, gerakan New Labour juga mengangkat isu kewarganegaraan, dan ini

${ }^{17} \mathrm{http}: / /$ re-searchengines.com/0806edi.html. (diakses 29 Desember 2013).

${ }^{18} \mathrm{http}: / / \mathrm{www}$.boyung.net/docs/Ideology and_policy_development_c1_analytical\%20 framework.pdf. (diakses 29 Desember 2013). 
terkait dengan relasinya terhadap welfare state dalam memenuhi hak-hak kaum buruh sebagai individu warga negara. ${ }^{19}$ Yang artinya kaum buruh diperlakukan setara dengan warga negara lainnya di ranah publik, terutama dalam mendapatkan hak-hak layanan publik, ${ }^{20}$ seperti kesehatan, urusan administartif, pendidikan, perumahan, perlindungan keamanan dan sebagainya.

Kemudian, New Labour juga mewacanakan isu gender dalam aksi perjuangannya. ${ }^{21}$ Isu gender semasa Old Labour tidak terangkat tapi oleh gerakan New Labour mulai mengemuka dan kencang untuk diperjuangkan. Buruh perempuan menjadi perhatian serius terkait dengan kesehatan reproduksinya selama dia bekerja. Hak cuti hamil tanpa pemberhentian kerja dan mendapatkan jaminan kesehatan selama hamil sampai dengan melahirkan menjadi isu yang sering diwacanakan oleh gerakan New Labour. Tidak hanya dalam masalah hal kesehatan reproduksi, kesetaraan gender antara buruh laki-laki dengan buruh perempuan dalam lingkungan kerja ataupun hak-hak upah kerja juga tidak luput menjadi isu yang diperjuangkan. Tuntutan atas isu-kesehatan reproduksi, tidak adanya penghapusan upah selama cuti hamil sampai dengan jaminan kesehatan selama melahirkan ditambah lagi kesetaraan dalam lingkungan kerja dan hak upah kerja-tidak hanya ditujukan ke pabrik tapi juga ke negara agar menjadi sebuah kebijakan publik yang pro gender.

New Labour juga merespon isu neoliberalisme. ${ }^{22}$ Semasa Old Labour belum

\footnotetext{
${ }^{19}$ Martin Powel. (1999). New Labour, New Welfare State?. Bristol: Policy Press.

${ }^{20}$ http://www.socialpolicy.ed.ac.uk/_data/ assets/pdf_file/0011/58709/New_Labour_and_ partnerships_in_public_health.pdf. (diakses 29 Desember 2013).

${ }^{21}$ Lister, R. (2000). 'Gender and The Analysis of Social Policy' in G. Lewis, S. Gewirtz and J. Clarke (Eds.) Rethinking Social Policy. London: Sage.

${ }^{22}$ Fairclough, N. (2000). New Labour, New Language?. London: Routledge.
}

sempat berhadapan dengan sistem ekonomi politik baru, yaitu neoliberalisme. New labour harus merespon neoliberal dengan sangat serius karena sistem tersebut sangatlah merugikan kepentingan buruh. Beberapa rumus pemikiran neoliberal yang sangat merugikan buruh yaitu, pertama, upah buruh diserahkan kepada pasar bebas dan intervensi negara atas kebijakan perburuhan harus diminimalisir. Kedua, pasar kerja buruh diatur dengan hukum "keynesian" (permintaan-penawaran) dan pasar kerja tersebut lebih fleksibel. Ketiga, serikat dagang diberikan ruang yang lebar dalam proses pembuatan kebijakan sektor industri dan perburuhan. Keempat, pemotongan biaya pelayanan publik yang disediakan negara (kesehatan, pendidikan, keamanan, dan sebagainya) agar negara bisa menurunkan pajak kaum pemilik modal dan kalau perlu biaya pelayanan sosial untuk buruh, negara yang urus bukan perusahaan. ${ }^{23}$

Masih terkait dengan neoliberalisme bahwa pergerakan New Labour kian progresif setelah pemikiran Tactherisme lahir dan berkembang di negara-negara Barat. ${ }^{24}$ Tacthcerisme membuat posisi buruh harus berhadapan dengan strong state dan disisi lain harus face to face dengan pasar bebas. Negara dalam konteks Tactherisme harus berposisi memuluskan kepentingan pasar, asumsinya pasarlah yang akan membawa kemajuan ekonomi bukan kaum buruh. Tactherisme memandang persoalan kesejahteraan buruh bisa diselesaikan dengan pertumbuhan ekonomi, tapi New Labour memandang adanya pertumbuhan ekonomi justru akan mengeklusi kepentingan buruh dan tidak ada "trickle down effect" (baca: efek menetes kebawah) kepada kesejahteraan buruh. Inilah yang membuat

\footnotetext{
${ }^{23}$ Uraian garis besar tentang neoliberalisme bisa dilihat lebih lanjut, Keith Faulks. (2012). Sosiologi Politik: Pengantar Kritis. Jakarta: Nusa Media, hlm. 120.

${ }^{24}$ http://www.lancaster.ac.uk/sociology/research/ publications/papers/jessop-from-thatcherism-tonew-labour.pdf. (diakses 30 Desember 2013).
} 
New Labour harus berjuang mencari strategi alternatif menghadapi kuatnya pengaruh Tatcherisme. $^{25}$

Kemudian sebagai lanjutan dari perjuangan mensiasati Tatcherisme, New Labour akhirnya mengusung isu a Third Way antara laissez-faire kapitalisme pasar, perencanaan ekonomi nasional top-down dan birokrasi welfarisme. Isu 'jalan ketiga' ini untuk menjembatani tekanan strong state bentukan Tactherisme dan liberalisasi pasar bebas. Dorongan isu ini untuk membuat pemerintah tidak terlalu otoriter dalam kebijakannya dan disisi lain juga untuk mendorong pihak swasta agar lebih mengintegrasikan kepentingannya dengan publik. Bahasa sederhananya yaitu menciptakan kemitraan publik-swasta yang berorientasi pada pelayanan publik terorientasi pada warga, dan disitulah hak-hak buruh bisa terakomodasikan. ${ }^{26}$

\section{Analisis dan Pembahasan}

\section{Isu Buruh Semasa Rezim Habibie}

Di bawah Pemerintahan B.J. Habibie. Lima isu-isu besar yang dihadapi oleh Habibie, yaitu (1) Masa depan reformasi; (2) Masa depan ABRI; (3) Masa depan daerah-daerah yang ingin melepaskan diri dari Indonesia; (4) Masa depan Soeharto dan keluarganya, kekayaannya dan kroni-kroninya; (5) Masa depan perekonomian dan kesejahteraan rakyat. 17 (tujuh belas) bulan kemudian isu pertama menunjukkan perkembangan positif. Isu ke dua mengarah pada pengurangan peranan militer di bidang politik. Isu ketiga terselesaikan dalam konteks

\footnotetext{
${ }^{25}$ Cochrane, A. (Eds)/1999. 'New Labour, New Urban Policy?', dalam H. Dean and R. Woods( Social Policy Review 11). London: Social Policy Association, hlm. 1.

${ }^{26}$ Benington, J. and Donnison, D. (Eds)/1999. 'New Labour and Social Exclusion: the Search for a Third Way - or just Gilding the Ghetto again?', dalam H. Dean and R. Woods(Social Policy Review 11). London: Social Policy Association, hlm. 4570.
}

Timor-Timur namun tidak pada daerah lain, isu ke empat belum terselesaikan dan isu kelima tetap tidak terpecahkan. ${ }^{27}$ Masalah perburuhan masuk isu ke lima.

Masalah perburuhan belum berhasil dituntaskan oleh Habibie pasca dia dilantik menjadi presiden. Isu perburuhan yang sempat menggoyang pemerintahan Habibie adalah aksi penolakan terhadap rencana pengesahan Rancangan Undang-Undang tentang Pembinaan dan Perlindungan Ketenagakerjaan (RUU PPK) menjadi undangundang (UU), Barangkali kesimpulan yang diambil pemerintah mengenai penolakan buruh terhadap UU No 25/1997 adalah karena buruh belum siap. Padahal, substansi persoalannya adalah materi undang-undang tersebut belum menyentuh upaya perlindungan hak-hak buruh secara memadai, bahkan merugikan. Dengan demikian, menjelang akan berlakunya undangundang ini di masa Presiden BJ Habibie, buruh dan masyarakat kembali melancarkan penolakan berlakunya. Kebijakan yang dipilih Presiden Habibie adalah mengeluarkan UU No. 11/1998, yang menunda berlakunya UU No. 25/1997 menjadi mulai tanggal 1 Oktober $2000 . .^{28}$

Selain itu, isu ratifikasi 9 Konvensi Perburuhan yang dikeluarkan oleh International Labour Organization (ILO), yang salah satunya menekankan hak kebebasan berserikat (Freedom of Association/Konvensi ILO No. 9 Z) bagi kaum buruh. Masih terkait ratifikasi, isu yang sempat menghangat juga adalah isu hak buruh untuk berunding (Collective Bargaining No. 9 G) yang sebenarnya telah diratifikasi semasa Soekarno tahun 1957 juga diangkat kembali. Di kalangan buruh sendiri isu ratifikasi konvensi hak buruh berserikat dan konvensi hak buruh berunding

${ }^{27}$ http://tyastyfa.blogspot.com/2012/05/masareformasi-indonesia.html. (diakses 30 Desember 2013).

${ }^{28}$ http://www.unisosdem.org/article_detail.php ?aid=491\&coid=2\&caid=20\&gid=1. (diakses 30 Desember 2013). 
ini ditanggapi pesimis karena dianggap hanya sebagai jargon politik Habibie untuk menarik perhatian dari kaum buruh. ${ }^{29}$

Di sisi lain, ada kebijakan Habibie yang cukup positif terhadapkaum buruh yaitu buruh mendapatkan keleluasaan untuk mendirikan organisasi atau perserikatan buruh. Tidak seperti masa Soeharto, organisasi buruh saat itu yang diperkenankan hidup cuma satu yaitu Serikat Pekerja Seluruh Indonesia (SPSI) tetapi pada masa Habibie ini puluhan organisasi buruh berdiri bahkan ada satu organisasi buruh yang membentuk partai agar bisa ikut Pemilu Juni 1999. Yang menarik adalah keputusan peninjauan ulang yang dilakukan Habibie atas Undang-Undang Ketenagakerjaan yang baru, hal ini menimbulkan reaksi negatif dikalangan buruh dan NGO karena tidak mencerminkan aspirasi dan kepentingan kaum buruh. ${ }^{30}$

Semasa pemerintahan Habibie ini, ada momen yang cukup mengejutkan juga ketika Habibie membebaskan tokoh pemimpin buruh yang dipenjara semasa OrdeBaru, yaitu Muchtar Pakpahan. ${ }^{31}$ Pada pembebasannya, Pakpahan

${ }^{29} \mathrm{http} / / /$ www.elsam.or.id/downloads/1326791999 Saepul_Tavip_-_Nestapa_Kaum_Buruh.pdf. (diakses 31 Desember 2013).

${ }^{30}$ Riwanto Tirtosudarmo. (2007). Mencari Indonesia: demografi-politik pasca-Soeharto. Jakart: LIPI Press, hlm. 271.

${ }^{31}$ Muhctar Pakpahan adalah tokoh buruh yang menyuarakan pembentukan serikat buruh di luar SPSI yang disebut dia sebagai serikat buruh boneka Orde Baru. Dia mendirikan Serikat Buruh Sejahtera Indonesia (SBSI). Akibat mendirikan serikat tersebut dia ditangkap dan ditahan oleh rezim Orba. Kemudian adanya pelarangan serikat buruh buruh dan penahanan aktivis buruh pada bulan Juni 1992 pemerintahan Clinton mengancam sanksi perdagangan terhadap Indonesia, didukung oleh petisi yang dikemukakan oleh Asia Watch dan International Labor Right Education dan Research Fund, keduanya merupakan badan-badan yang dibiayai oleh pemerintah AS dan mempunyai hubungan dekat dengan CIA dan Amerika Serikat buruh birokrasi, AFL-CIO. Petisi tersebut lahir karena menurut laporan bahwa Soeharto mengontrol ketat serikat buruh, dan serikat buruh mendesak Habibie untuk mengumpulkan boneka-boneka Majelis Permusyawaratan Rakyat (MPR) untuk memilih seorang presiden peralihan. Seperti burjuis oposisi lainnya, Pakpahan mendesak bahwa semua tuntutan untuk reformasi harus dibatasi dalam cara bekerja politis yang sempit. Pakpahan juga mengusulkan kepada Habibie untuk pembentukan sebuah partai buruh (labour party). Namun, hanya beberapa hari setelah membebaskan Muchtar Pakpahan, pemerintah Habibie membuat larangan kepada badan serikat buruh yang telah dikepalai Pakpahan selama 6 tahun, yaitu Serikat Buruh Sejahtara Indonesia (SBSI). ${ }^{32}$

\section{Isu Buruh Semasa Rezim Megawati}

Awalnya gerakan buruh optimis atas terpilihnya Megawati sebagai presiden. Buruh berharap banyak kepada kepemimpinan Megawati yang selama ini dianggap sebagai pembela "wong cilik". Tetapi gerakan buruh mulai kecewa kepada Megawati tatkala mengurangi subsidi listrik dan menaikan harga Bahan Bakar Minyak (BBM) sebesar 30 persen pada Oktober 2001, sebagaimana tercantum dalam Rancangan Anggaran Pendapatan dan Belanja Negara (RAPBN) 2002. Kebijakan Megawati menaikan harga BBM dan menurunkan subsidi listrik tersebut akan berdampak langsung pada kesejahteraan kaum buruh karena kenaikan BBM tersebut tidak diimbangi dengan peningkatan gaji buruh. ${ }^{33}$

Buruh tambah kecewa lagi kepada Megawati karena justru menaikan anggaran

yang diperbolehkan berdiri hanya satu, yaitu SPSI dan itupun jumlah anggotanya hanya 6 persen dari jumlah seluruh buruh di Indonesia padahal di dunia internasional SPSI membawahi jutaan buruh. Lihat lebih lanjut, https://www.wsws.org/ en/articles/1998/05/pemb-m28.html. (diakses 30 Desember 2013).

${ }^{32}$ https://www.wsws.org/en/articles/1998/05/pembm28.html. (diakses 30 Desember 2013).

${ }^{33}$ Kompas. 10 September, 2001. Buruh Khawatir atas Peningkatan Anggaran Militer. 
belanja militer sampai 18 persen tatkala buruh mengeluhkan isu kenaikan BBM. Akhirnya buruh menggelar Rapat Akbar di halaman Tugu Proklamasi Jakarta untuk protes atas kebijakan Megawati menaikan harga BBM tersebut, aksi tersebut dipimpin langsung oleh Dita Indah Sari sebagai Ketua Umum Front Nasional Perjuangan Buruh Indonesia (FNPBI). ${ }^{34}$

Saat menggelar rapat akbar tersebut, disamping mengangkat isu penolakan kenaikan BBM, gerakan buruh juga mengangkat isu perlunya konsolidasi penyatuan serikatserikat buruh untuk memperjuangkan hak-hak buruh. Alasan mengangkat isu konsolidasi penyatuan serikat-serikat buruh dikarenakan buruh tidak bisa lagi mengandalkan seorang menteri ataupun presiden, perubahan nasib buruh sangat tergantung pada kekuatan serikat buruh. Dita Indah Sari yang memimpin rapat akbar saat itu menekankan perlunya sebuah aliansi permanen perburuhan untuk melawan kekuatan dominasi kapitalisme global dan harus lepas dari kepemimpinan buruh lama yang masih menghamba kekuasaan, sebagaimana yang diungkapkan Dita Indah Sari sebagai berikut:

"Dita mengungkapkan, gerakan buruh di Tanah Air sampai sekarang masih didominasi kekuatan-kekuatan dan pemimpin lama. Menurut dia, perlu waktu lebih lama untuk memberikan kesadaran dan pembuktian kepada kalangan buruh mana pilihan-pilihan terbaik. Organisasi buruh yang baru harus bisa membuktikan bahwa program mereka lebih baik, kepemimpinan mereka lebih orisinil, dan berjarak dengan kekuasaan. Dita menambahkan mencoba membangun aliansi yang lebih permanen di kalangan serikat buruh. Selama ini mereka baru melakukan aliansi bila menghadapi sebuah isu atau kasus. Kami ingin membangun

${ }^{34} \mathrm{Ibid}$. aliansi yang lebih besar dan berjangka panjang tetapi dimulai dari persoalan sehari-hari." ${ }^{35}$

Di samping mengangkat isu-penolakan kenaikan BBM, penguatan dan penyatuan serikat buruh, kepemimpinan buruh, dan otonomisasi serikat buruh dari kekuasaanburuh semasa megawati juga mengangkat isu musuh baru gerakan buruh yaitu partaipartai politik yang melupakan mereka. Selain menghadapi pengusaha dan penguasa, kini buruh bertambah musuhnya yaitu partai politik. Hal ini ditandaskan oleh Dita Indah Sari, Ketua Umum FNPBI sebagai berikut.

"Tidak sedikit pun bahkan satu alinea saja, pidato politik dari Megawati Soekarnoputri yang bagus itu menyinggung nasib kaum buruh. Padahal jelas PDI-P dan Megawati berhutang pada kaum buruh yang sebagian di antaranya memilih PDI-P pada saat pemilu kemarin," ujar Dita Indah Sari, aktivis perburuhan yang sempat mendekam di penjara Tangerang... Memang gerakan buruh butuh lebih banyak tenaga untuk menggolkan tuntutannya. Bukan sekadar tuntutan ekonomi seperti kenaikan upah, tetapi juga tuntutan politik untuk menyuarakan aspirasi mereka dalam wacana politik yang lebih luas seperti di parlemen, partai politik dan media massa. Seperti kata Dita, "Kita tidak bisa memisahkan tuntutan ekonomi dan politik karena keduanya sangat dialektis dan saling mempengaruhi". ${ }^{36}$

Dari keterangan Dita Indah Sari tersebut, ada isu penting juga yang diangkat oleh buruh selain masalah tuntutan ekonomi yaitu isu politik. Buruh saat itu tidak lagi melihat

\footnotetext{
${ }^{35}$ Ibid.

${ }^{36} \mathrm{http}: / /$ www.minihub.org/siarlist/msg03528.html. (diakses 30 Desember 2013)
} 
tuntutan ekonomi sebagai isu tersendiri tapi juga sebagai isu yang sangat korelatif dengan isu politik. Melekatkan tuntutan ekonomi dengan ranah politik adalah sebuah isu yang cukup hangat di kalangan buruh saat itu. Aliansi buruh mau tidak mau harus bersentuhan dengan parlemen, partai politik, dan media massa dalam memperjuangkan hakhak buruh. Oleh sebab itu, semasa Megawati, buruh mulai serius memperhatikan isu politik sebagai isu strategis yang harus mereka jamah dan bukan lagi sebagai isu yang tabu.

Kemudian, isu perburuhan yang tak kalah panasnya di era Megawati adalah pengesahan Undang-Undang Pembinaan dan Perlindungan Ketenagakerjaan (UU PPK) dan pengesahan Undang-Undang Penyelesaian Hubungan Indsutril (UU PPHI). Rencana pengesahan kedua UU tersebut memunculkan reaksi keras dari kalangan buruh. Pada 22 Maret 2003 ribuan buruh aksi turun ke jalan menolak pengesahan kedua tersebut. Ribuan buruh menuju Bundaran Hotel Indonesia, lalu berdemontrasi di depan Istana Negara, dan gedung Perserikatan Bangsa-Bangsa. ${ }^{37}$

Alasan buruh saat itu menolak keras kebijakan pemerintahan Megawati mengesahkan UU PPK dan PPHI yaitu, pertama secara substansi, UU ini tidak memberi perlindungan bagi buruh. Perlindungan dalam banyak hal, termasuk para wanita, yang secara kodrati harus haid. Haid bulanan yang tidak bisa dihindari sehingga berpengaruh kepada pelaksanaan tugas kerjanya. Kedua, UU ini diciptakan guna melindungi pemilik modal internasional dan buruh menunjuk lembaga internasional seperti IMF, ADB, dan Bank Dunia sebagai dalang di balik pengesahan itu. DPR dan pemerintah tak bisa menolak desakan dan tekanan lembaga internasional itu karena mereka telah bersepakat dalam Structural Adjustment Program (SAP). Perjanjian ini telah mengubah perlindungan negara terhadap buruh

\footnotetext{
${ }^{37}$ http://www.balipost.co.id/BALIPOSTCETAK/ 2003/3/26/n2.htm. (diakses 9 Januari 2014)
}

menjadi flexible labour market. Kepentingannya agar kapitalis internasional bisa berinvestasi secara kondusif. Ketiga, UU telah menghilangkan jaminan hak atas pekerjaan. Jaminan hak ini tidak dicantumkan secara jelas dan tegas karena munculnya pasal mengenai sistem kerja kontrak (perjanjian kerja waktu tertentu). Keempat, undang-undang ini pun melegalisasi praktik sistem kerja kontrak ilegal (subkontrak/ outsourcing). Kelima, UU ini telah melegalisasi upah murah agar investasi di dalam negeri terus berkembang. Keenam, hak mogok kerja diatur dan serikat buruh dikebiri melalui UU ini. ${ }^{38}$

\section{Buruh Semasa Rezim Gus Dur}

Gerakan buruh semasa Presiden Abdurahman Wahid (Gus Dur) mendapatkan sebuah angin politik yang cukup akomodatif. Semasa menjadi presiden, Gus Dur langsung mengakomodasi kepentingan buruh yang menuntut pembatalan UU No. 25 Tahun 1997 tentang Ketenagakerjaan. Beleid ini ditentang habis-habisanoleh kaumburuhIndonesiakarena substansinya sangat eksploitatif. Pembatalan UU No 25/1997 ini untuk mengantisipasi adanya kekosongan hukum ketenegakerjaan karena UU pengganti UU No. 25 Tahun 1997 belum ada, pada 25 September 2000 dibuat Peraturan Pemerintah Pengganti UndangUndang (Perpu) No. 3 Tahun 2000 tentang Perubahan atas UU No. 11 Tahun 1998 tentang Perubahan Berlakunya Undang-Undang No. 25 Tahun 1997 tentang Ketenagakerjaan. Perpu ini kembali menunda berlakunya UU No 25 Tahun 1997 yang semestinya berlaku pada Oktober 2000 menjadi Oktober 2002 dan pemerintahan Gus Dur segera mengajukan RUU perburuhan yang baru. ${ }^{39}$

\footnotetext{
${ }^{38} \mathrm{http}$ ://www.balipost.co.id/BALIPOSTCETAK/ 2003/3/26/n2.htm. (diakses 9 Januari 2014)

Lihat juga, "RUU PPK dan PHI Disahkan Meski Ditentang", dalam http://www.pelita.or.id/baca. php?id=7721. (diakses 9 Januari 2014)

${ }^{39}$ http://www.gusdur.net/opini/Detail/?id=195/hl=id/ Pembela_Sejati_Kaum_Buruh_Migran. (diakses 30 Desember 2013).
} 
Di samping pembatalan UU No 25 Th 1997 tersebut Gus Dur juga merangkul dan mengadakan pertemuan reguler dengan kalangan aktivis buruh dan NGO untuk merumuskan kebijakan perburuhan. Salah satu isu yang didiskusikan adalah isu buruh migran. Alhasil dari diskusi tersebut terbitlah Peraturan Menteri Tenaga Kerja No 150 Tahun 2000 tentang Penyelesaian Pemutusan Hubungan Kerja dan Penetapan Upah Pesangon, Uang Penghargaan dan Ganti Rugi oleh Perusahaan. Bagi kaum buruh, Permenaker No 150/2000 ini merupakan kebijakan yang pro buruh berhadapan dengan pengusaha. ${ }^{40}$

Isu buruh migran belum sempat diperhatikan oleh Habibie maupun Megawati, tapi ketika Gus Dur isu ini menjadi sebuah isu yang cukup menonjol semasa pemerintahan Gus Dur. Fokus Gus Dur untuk menangani isu buruh migran ini terkait laporan masalahmasalah buruh migran yang selama ini sangat memprihatinkan realitanya. Mulai dari penyiksaan oleh majikan, pemerkosaan Tenaga Kerja Wanita (TKW), TKI yang menjalani hukuman mati di negara tempat mereka bekerja, ${ }^{41}$ upah dan pesangon yang dilanggar oleh agen maupun majikan, maupun layanan pemerintah yang kurang humanis dan protektif dalam memenuhi hak-hak buruh migran.

Selain isu buruh migran, isu pelegalan pemerintah atas serikat buruh juga naik lagi. Isu kebebasan berserikat kaum buruh ini ditanggapi Gus Dur dengan mengesahkan UU No. 21 Tahun 2000 tentang Serikat Pekerja/ Serikat Buruh. ${ }^{42}$ Dengan kebebasan itu, 10

\footnotetext{
${ }^{40}$ http://www.gusdur.net/opini/Detail/?id=195/hl=id/ Pembela_Sejati_Kaum_Buruh_Migran. (diakses 30 Desember 2013).

${ }^{41}$ Gus Dur pernah melakukan kontak langsung penguasa Arab Saudi Raja Fahd dan meminta pembatalan pelaksanaan hukuman mati terhadap Siti Zaenab. Berkat diplomasi tingkat tinggi tersebut, nyawa Siti Zaenab terselamatkan walau hingga kini proses hukum terhadap Siti Zaenab belum tuntas.

${ }^{42}$ http://www.nu.or.id/a,public-m,dinamic-s,detailids,44-id,44169-lang,id-c,nasional t, Gus+Dur+ +Pembebas+Gerakan+Buruh-.phpx. (diakses 30
}

orang bisa mendirikan 1 serikat buruh. Adanya kebebasan mendirikan serikat buruh ini, gerakan buruh mulai mendapatkan tempat di ruang publik untuk mengangkat isu-isu yang diperjuangkannya. Tetapi munculnya isu serikat buruh ini justru menimbulkan perpecahan di internal gerakan buruh sendiri.

Perpecahan serikat tidak hanya melanda SPSI, tetapi juga serikat-serikat eks-SPSI dan non-SPSI. Perbedaan-perbedaan yang sifatnya pragmatis-dalam arti lebih disebabkan oleh hal-hal praktis daripada hal-hal prinsip-lebih mewarnai sebab perpecahan serikat. ${ }^{43}$ Pada umumnya perpecahan diikuti oleh perebutan atau pembagian anggota. Ada kalanya anggota bahkan tidak tahu bahwa di tingkat nasional serikatnya sudah pecah. Keputusan anggota untuk bergabung di salah satu serikat yang pecah lebih didasari oleh kedekatan personal dengan para pengurus dibanding hal-hal yang bersifat prinsip organisasi. ${ }^{44}$

\section{Isu Buruh Semasa Rezim SBY}

Ada empat isu yang dijanjikan SBY ketika dia pertama kali terpilih menjadi presiden, empat isu tersebut adalah pemerintahan yang bersih, pemerintahan yang demoktratis, pemerintahan yang berdaulat, dan pemerintahan yang mempunyai karakter kerakyatan. Keempat janji SBY tersebut ternyata justru menjadi "bumerang" tersendiri bagi SBY karena tidak bisa memenuhi janji tersebut. Salah satu janji SBY yang ditagih gerakan buruh pasca dia

\footnotetext{
Desember 2013).

${ }^{43}$ Vedi Hadiz, op.cit.
}

${ }^{44}$ Lihat Indrasari Tjandraningsih, 'Serikat Buruh/ Serikat Pekerja di Indonesia: Sebuah Potret Pasca Reformasi. Dalam http://indoprogress.blogspot. com/2007/08/serikat-buruhserikat-pekerja-di. html. Indrasari menjelaskan dalam tulisannya tersebut bahwa perpecehan di internal buruh terkait isu serikat buruh, yaitu karena tiga (3) faktor. Pertama, rapuhnya pengorganisasian. Kedua, tidaknya menyatunya ideologi dan gerakan serikat buruh. Ketiga, serikat buruh terjebak ekslusivisme. 
terpilih menjadi presiden adalah masalah kesejahteraan buruh. Gerakan buruh melalui wadah Front Nasional Persatuan Buruh Indonesia (FNBI) menagih janji presiden terpilih Susilo Bambang Yudhoyono saat itu. Budi Wardoyo pejabat sementara Sekjen FNPBI saat itu mengatakan mereka menagih janji good government yang pernah dijanjikan SBY semasa menjadi calon presiden, yang salah satunya peningkatan kesejahteraan buruh. ${ }^{45}$ Saat awal pemerintahan SBY, gerakan buruh sudah mengalami kekecewaan atas sikap pemerintah yang "plin-plan" tersebut.

Semasa SBY ini gerakan buruh mendapatkan tantangan yang cukup serius terkait isu Pemutusan Hubungan Kerja (PHK), kerja sistem kontrak, dan kerja sistem outsourcing. Sepuluh tahun terakhir jumlah PHK massal meningkat pesat karena gejala de-industrialisasi atau kehancuran industri nasional. Gejala deindustrialisasi ini sebagian besar disebabkan oleh kebijakan ekonomi neoliberal yang diamdiam dijalankan oleh pemerintah. Adanya kebijakan neoliberal tersebut UMK/UMP yang diterima buruh diserahkan pada pasar dan pemerintah hanya menjadi wasit saja sehingga ketika buruh menuntut kenaikan UMK/UMP maka perusahaan dimana dia bekerja segera melakukan ancaman PHK kepada buruh yang protes, ironisnya pemerintah kadangkala diam saja dan tidak memberikan perlindungan jaminan kerja kepada buruh. Pengurangan beban kapital dengan disertai pencerabutan perlindungan hak-hak buruh merupakan bagian dalam rangka mendukung disain dan pelaksanaan sistem neoliberal.

Salah satu contoh kasus ancaman PHK yang dikeluarkan oleh kalangan pengusaha yaitu ketika Forum Pengusaha Penanam Modal Asing (FPPMA) Subang yang merupakan konsorsium 25 perusahaan garmen asal Korea Selatan berencana akan mengurangi jumlah

\footnotetext{
$\overline{45}$ http://www.tempo.co/read/news/2004/10/ 11/05549214/ Front-Nasional-Buruh-Tagih-Janji-SBY. (diakses 30 Desember 2013).
}

buruh jika Gubernur Jawa Barat menyetujui UMK Subang sebesar Rp1,557 juta sesuai rekomendasi Bupati Subang, Ojang Sohandi dan sekitar 50.000 buruh terancam terkena pemutusan hubungan karyawan (PHK) jika PHK dilakukan oleh perusahaan. ${ }^{46}$ Kasus-kasus ancaman PHK semacam ini banyak sekali terjadi semasa pemerintahan SBY, masalahnya tidak hanya karena buruh menuntut kenaikan upah saja, tetapi perusahaan juga "warning" keras keluarkan PHK jika serikat buruhnya kritis. ${ }^{47}$ Ancaman PHK semacam ini menghantui para buruh ketika mereka menuntut hakhak perburuhan, dan masalahnya tidak ada jaminan dan advokasi perlindungan jaminan kerja bagi buruh dari pemerintah.

Masih terkait dengan tidak adanya jaminan kerjabagiburuh, masalah penghapusan kerja kontrak dan sistem outsourcing juga menjadi agenda isu yang diperjuangkan oleh gerakan buruh semasa rezim SBY. Sistem kerja kontrak dan sistem kerja outsourcing dianggap sangat melanggar Hak Asasi Manusia (HAM) buruh. Pemerintah sebenarnya sudah memberikan jaminan perlindungan kerja buruh dari sistem kontrak maupun outsourcing dengan mengeluarkan Undang-Undang No. 13 Tahun 2003 tentang Ketenagakerjaan tetapi dalam implementasinya ketika buruh terkena dampak kerugian sistem kontrak dan outsourcing ternyata pemerintah diam saja. Undang-undang tersebut bagi buruh terkesan definitif dan normatif saja tetapi tidak ada political will untuk advokasi perlindungan hak buruh. Oleh sebab itu, walaupun pemerintah sudah menjamin dengan undang-undang atas sistem kontrak dan outsourcing tetapi gerakan buruh meminta pemerintah menghapus sistem kerja kontrak dan outsourcing tersebut.

\footnotetext{
${ }^{46}$ http://www.jpnn.com/read/2013/11/22/202132/RibuanKaryawan-Terancam-PHK-. (diakses 30 Desember 2013).

${ }^{47}$ http://www.rmol.co/read/2013/08/01/120510/Buruh-DiCakung-Ngadu-Ke-Kantor-Komnas-HAM-. (diakses 30 Desember 2013).
} 
Isu tuntutan penghapusan kerja kontrak dan outsourcing ini mengalami momen titik puncak ketika gerakan buruh yang tergabung dalam wadah Majelis Pekerja Buruh Indonesia $(\mathrm{MPBI})^{48}$ menggalang aksi mogok nasional besar-besaran yang pertama kali di Indonesia pada 3 Oktober 2012 di Jakarta untuk menuntut penghapusan outsourcing dan tolak upah murah. Dari hasil aksi mogok nasional tersebut ada 50.000 buruh yang berhasil diubah statusnya dari outsourcing menjadi pekerja yang memiliki hubungan langsung dengan perusahaan. ${ }^{49}$

Disamping merespon isu outsourcing, MPBI juga merespon isu penolakan RUU Badan Penyelenggara Jaminan Sosial (BPJS). Banyak yang heran karena pada awalnya, RUU ini bertujuan untuk menjamin hak-hak dasar warga negara, terutama para buruh dan masyarakat kalangan bawah. Namun, penolakan terjadi karena draf RUU justru dinilai memuat pelanggaran mendasar terhadap hakhak dasar warga negara. Ada sejumlah alasan yang digulirkan oleh gabungan serikat pekerja dan lembaga swadaya masyarakat terkait penolakan RUU BPJS saat ini. Mereka menilai, UU Sistem Jaminan Sosial Nasional (UU SJSN) sebagai induk dan RUU BPJS dinilai telah memanipulasi jaminan sosial menjadi asuransi wajib. Filosofi jaminan sosial dicampuradukkan dengan prinsip-prinsip asuransi karena masyarakat diminta melakukan iuran seperti sistem premi. ${ }^{50}$ Di sisi lain, ada gerakan buruh yang mendukung disahkannya RUU BJPS. Salah satu wadah gerakan buruh yang pro pengesahan BJPS adalah FSPMI, berikut pernyataan Obon Tobroni, Komandan Garda Metal FSPMI dalam menyikapi isu BJPS.

\footnotetext{
${ }^{48}$ MPBI terdiri atas 3 konfederasi buruh: KSPI, KSPSI, dan KSBSI.

${ }^{49} \mathrm{https} / / /$ docs.google.com/document/d/1S7 Y 0 qCVgKm VWo5 BrZ_NKiaqE4EEJK8S1 BbVq8EwDE_Y/edit?pli=1. (diakses 7 Januari 2014).

${ }^{50} \mathrm{http}: / /$ nasional.kompas.com/read/2011/07/13/15490676/ Alasan.Serikat.Buruh.Menolak.RUU.BPJS. (diakses 7 Januari 2013).
}

\begin{abstract}
"Bagi saya BJPS disikapi positif saja, yang penting disahkan dulu oleh pemerintah sebagai bentuk uji political will pemerintah untuk kesejahteraan kaum buruh maupun rakyat miskin, masalah isu bahwa iuran yang dikenakan akan membebani para buruh bagi FSPMI tidak masalah, kan ada perimbangan potongan iuran yang dikenakan buruh dengan pengusaha, misalnya kalau buruh 1 persen dari penghasilan per bulan kalau pengusaha $2 \times 1$ persen dari omzet dia per bulan. Lebih baik dipotong secara rutin daripada dibiarkan para buruh menabung sendiri-sendiri untuk jaminan pensiun mereka karena kalau buruh menabung pun gajinya sudah habis sebelum pertengahan bulan, makanya adanya iuran yang terlembagakan tersebut malah lebih antisipatif."51
\end{abstract}

Kemudian, isu bahwa BJPS adalah utang luar negeri dan harus ditolak oleh buruh ditanggapi oleh Jamaludin, Ketua Komite Aksi Jaminan Sosial (Surabaya). Dia mengatakan bahwa:

"BJPS adalah hasil perjuangan buruh selama 3 sampai 4 tahun terakhir ini, isu BJPS adalah utang luar negeri bagi saya perlu diklarifikasi karena semua anggaran BJPS dibebankan dalam APBN dan APBD, setidak-tidaknya BJPS dilihat sebagai bentuk reformasi jaminan sosial yang beda dengan Jamsostek masa lalu karena sistem pertanggungjawaban keuangan Jamsostek sangat tidak transparan bahkan diinvestasikan untuk perusahaan-perusahaan seperti Bank Century atau PT. Merpati yang jelasjelas sarang korupsi. Kalau Jamsostek, Askes dan lain-lain dulu dikelola oleh Perseroan yang tentu saja misinya adalah profit oriented sedangkan BJPS lebih berorientasi nirlaba. Kemudian, BJPS sudah memiliki kewenangan

${ }^{51}$ Hasil wawancara dengan Obon Tobroni, Komandan Garda Metal FSPMI, tanggal 7 Januari 2014. 
super body untuk law enforcement ketika ada perusahaan atau rumah sakit yang tidak mau menunaikan kewajibannya memberikan jaminan sosial kepada buruh sebagaimana yang tertera dalam undang-undang BJPS Kesehatan yang disahkan per 1 Januari 2014 kemarin." 52

Kemudian 28-31 Oktober 2013 gerakan buruh dalam wadah Konsolidasi Nasional Gerakan Buruh Indonesia (KNGBI) melakukan juga aksi mogok nasional di Jakarta besarbesaran yang diikuti jutaan massa buruh. Aksi gerakan buruh ini menuntut lagi penghapusan outsourcing, ditambah menuntut kenaikan upah 50 persen, dan tolak Inpres tentang Pengupahan. ${ }^{53}$ Aksi mogok nasional ini sempat membuat genting pemerintah SBY karena dianggap melabilkan situasi politik dan ekonomi nasional, bahkan ada 16 perusahaan yang sempat macet berproduksi selama aksi mogok nasional tersebut. ${ }^{54}$

Ditengah geliat aksi mogok nasional tersebut di kalangan gerakan buruh juga muncul isu rencana pendirian partai kelas buruh sebagai representasi tunggal nasional kaum buruh di Indonesia. Isu ini hanya menjadi perbincangan tapi cukup menghangat bahkan sampai menimbulkan polemik tersendiri di kalangan internal gerakan buruh, ada yang menolak tapi juga ada yang setuju atas isu rencana pendirian partai kelas buruh tersebut. Bagi gerakan buruh yang menolak dibentuk partai buruh alasannya nanti gerakan buruh justru akan terjadi fragmentasi, eklusivisme,

\footnotetext{
${ }^{52}$ Hasil wawancara dengan Jamaludin, Ketua Komite Aksi Jaminan Sosial Surabaya, tanggal 7 Januari 2014.

${ }^{53}$ http://www.antaranews.com/berita/401348/buruhberencana-gelar-mogok-nasional-28-30-oktober. Lihat juga http://www.republika.co.id/berita/nasional/ jabodetabek-nasional/13/10/31/mvj5dc-buruh-demodepok-tutup-tiga-jam. (diakses 7 Januari 2013).

${ }^{54} \mathrm{http}: / / \mathrm{www}$.metrotvnews.com/metronews/ $\mathrm{read} / 2013 / 11 / 02 / 5 / 191995 / 16-P e r u s a h a a n-T e r k e n a-$ Dampak-Aksi-Mogok-Nasional. (diakses 7 Januari 2014).
}

dan elitisme di kalangan gerakan buruh sendiri. ${ }^{55}$ Tapi bagi kalangan gerakan buruh yang lain justru momen 2014 menjadi test case bagi gerakan buruh untuk Go Politic. Bentuk Go Politic ini bisa dengan beberapa model. Pertama, buruh mendelegasikan orangnya di sebuah partai politik untuk dijadikan calon legislatif yang mewakili kaum buruh tapi dalam bendera sebuah partai politik. Orang ini tidak perlu seorang ketua serikat, ketua federasi, atau ketua konfederasi tapi buruh lapangan yang bisa dikontrol oleh dewan pimpinan gerakan buruh. Tuntutan terhadap para legislator dari gerakan buruh tersebut tidak perlu yang tinggitinggi misalnya dia harus bisa amandemen sebuah undang-undang ataupun mengegolkan sebuah undang-undang, tapi cukup dia mau hadir di lapangan saat buruh melakukan aksi demontrasi atau mogok. Asumsinya jika gerakan buruh saat aksi demonstrasi di lapangan dan disitu ada anggota legislatif tentu saja dampak politiknya juga beda dibanding aksi tapi tidak ada anggota dewan. ${ }^{56}$

Bentuk Go Politic kedua, yaitu membeli partai politik, yaitu gerakan buruh membuat deal atau semacam kontrak politik dengan partai politik untuk bisa mengegolkan isu-isu yang diperjuangkan buruh menjadi agenda kebijakan partai politik yang nantinya menjadi bahasan rancangan undang-undang di parlemen. Ketiga, manfaatkan partai politik. Misalnya saja yang dilakukan FSPMI yaitu menjadikan Rieke Dyah Pitaloka Anggota DPRI dari PDI-P sebagai jembatan politik buruh di parlemen. Walaupun cara ini sering dikritik banyak orang tapi gerakan buruh semacam FSPMI butuh cara itu, minimal mengetahui perkembangan informasi yang sedang digodok di parlemen. Keempat, adalah dengan membentuk partai politik tapi pertimbangannya cukup berat butuh proses dan belajar dari masa lalu ketika

\footnotetext{
${ }_{55}$ Hasil wawancara dengan Akbar Rewako, KASBI dan Sekber Buruh, tanggal 7 Januari 2014.

${ }^{56}$ Hasil wawancara dengan Obon Tobroni, Komandan Garda Metal FSPMI, tanggal 7 Januari 2014.
} 
Muktar Pakpahan membentuk partai buruh dan gagal. ${ }^{57}$ Tapi isu pembuatan partai baru akan benar-benar dibuktikan gerakan buruh nanti pada 2019.

Di sisi lain, isu tumbuhnya kesadaran politik kaum buruhbaik itu dikalangan personal maupun kolektif juga makin kentara. Beberapa tokoh buruh tersebut mulai melirik ranah politik parlementarian sebagai area perjuangan hak buruh walaupun secara konsesus organisasi perburuhan belum ada pernyataan resmi yang mewajibkan anggotanya untuk terjun ke dunia politik praktis. ${ }^{58}$ Gerakan buruh dengan adanya isu Go Politic tersebut berusaha membangun kesadaran politik internal besar-besaran melalui pendidikan ekonomi politik (ekopol). Buruh sadar perjuangan mereka tidak bisa diwilayah ekonomi saja tetapi semuanya ditentukan oleh politik sehingga kesadaran politik dan pengetahuan politik adalah dasar wajib gerakan buruh sebelum membentuk partai politik di $2019 .{ }^{59}$

Lalu, disamping tertarik di isu terjun ke dunia politik praktis, gerakan buruh ternyata juga pernah mengadvokasi isu INPRES KAMNAS, RUU KAMNAS, dan RUU ORMAS. Isu yang diangkat gerakan buruh semasa SBY ini tergolong isu lintas sektoral dan tidak hanya masalah hubungan industrial antara buruh dan pabrik. Hal ini menarik untuk diamati sebagai parameter bahwa buruh mengalami peningkatan kesadaran kritis atas masalah politik di luar politik perburuhan saja. Alasan gerakan buruh menolak rancangan kebijakan pemerintah tersebut dikarenakan ketiga aturan tersebut bersifat represif dan lebih mengedepankan pendekatan keamanan dalam menghadapi gerakan sosial dan gerakan buruh yang berjuang untuk masalah kesejahteraan

\footnotetext{
${ }^{57}$ Hasil wawancara dengan Obon Tobroni, Komandan Garda Metal FSPMI, tanggal 7 Januari 2014.

${ }^{58}$ Hasil wawancara dengan Akbar Rewako, KASBI dan Sekber Buruh, tangal 7 Januari 2014.

${ }^{59}$ Hasil wawancara dengan Jamaludin, Ketua Komite Aksi Jaminan Sosial Surabaya, tanggal 7 Januari 2014.
}

dan keadilan. ${ }^{60}$ Aksi penolakan terhadap ketiga peraturan tersebut dilakukan besar-besaran oleh gerakan buruh dalam wadah FSPMI, bahkan aksi demontrasinya berada di depan istana negara pada 6 Februari 2013.

Di samping isu Go Politic, gerakan buruh juga menggulirkan isu gender dalam wilayah aksinya. Isu gender mulai digarap benar-benar oleh salah satu gerakan buruh yaitu Federasi Buruh Lintas Pabrik (FBLP). Jumisih selaku Ketua FBLP mengatakan bahwa hampir sebagian besar pabrik-pabrik dihuni oleh kaum perempuan tapi isu pembelaan buruh perempuan jarang diangkat ke publik. Buruh perempuanlah penggerak roda kapitalisme tapi di saat yang sama buruh perempuan menjadi korban terbesar dari kapitalisme. Berikut hasil diskusi dengan Jumisih ketua FBLP. ${ }^{61}$

\begin{abstract}
"Semua perempuan adalah pekerja, di perusahaan diupah murah, di rumah tidak diupah. Kapitalis mengambil untung besar dari kerja perempuan di rumah; misalnya mendapat pekerja sehat terawat, ada yang siapkan makan di setiap rumah pekerja, tersedia selalu tenaga baru dan muda dll. Itu semua kerja perempuan, kerja besar yang tanpa bayar. Semakin besar kebutuhan dipenuhi di rumah, semakin ringan kapitalis tentukan upah murah. Kapitalis jelas ambil untung daribudaya patriarki. Selama buruh membenarkan perempuan kerja tanpa bayar, akan lebih kecil tuntutan upah. Makanya jika hanya mengandalkan ketrampilan dan bukan keahlian, atas nama industri padat karya, upah murah buruh perempuan pun jarang yang dibela."
\end{abstract}

Kemunculan isu kepemimpinan tunggal gerakan buruh juga sempat mengemuka tapi isu itu jarang terang-terangan di bawa

\footnotetext{
${ }^{60} \mathrm{http}: / /$ ekbis.sindonews.com/read/2013/02/06/34/714899/ ini-alasan-buruh-tolak-ruu-kamnas-dan-ruu-ormas

${ }^{61}$ Diskusi dengan Jumisih di Social Movement Institute, Yogyakarta.
} 
ke forum karena masih sensitif. Suara kepemimpinan tunggal gerakan buruh lebih banyak disuarakan oleh gerakan-gerakan buruh daerah yang masih belum terorganisir dengan baik dan belum bisa mengkonsolidasi massa banyak. Banyak dari kalangan buruh daerah yang berharap setiap serikat atau federasi buruh mau melepaskan seragam masing-masing dan tidak terlalu menonjolkan sebuah chauvinisme dan eklusivisme kelompok. Isu solidaritas gerakan buruh yang selama ini terbangun di kota-kota yang gerakan buruhnya masif, semisal Jakarta, Bogor, Tangerang, dan Bekasi (Jabotabek) plus Surabaya, harapannya bisa menular ke gerakan-gerakan buruh daerah.

Gerakan-gerakan buruh daerah mulai mengarah pada penguatan isu konsolidasi buruh daerah sebagai kritik konstruktif atas mati surinya gerakan buruh daerah dan selalu kalah jika berhadapan dengan pemerintah dan pasar. Gerakan buruh daerah perjuangan isunya masih sekitar masalah hubungan industrial dan belum merambat ke isu Go Politic sebagaimana gerakan buruh di kota-kota besar yang disebutkan dimuka.

\section{Kesimpulan}

Setiap pergantian rezim pasca reformasi 1998 ternyata ada perkembangan isu yang gerakan buruh gulirkan dan perjuangkan. Saat rezim Habibie, isu yang berkembang adalah pembebasan tokoh buruh, ratifikasi konvensi perburuhan, pendirian serikat buruh, dan otonomisasi perburuhan dari kooptasi dan intervensi penguasa. Kemudian, saat rezim Megawati isu buruh mulai merambah ke wilayah kebijakan pemerintah, yaitu isu penolakan kenaikan BBM, isu menolak kenaikan anggaran militer, isu menolak disahkannya UU PPK dan UU PHI, isu kepemimpinan buruh yang kuat, dan isu konsolidasi penyatuan serikat buruh.

Lalu, semasa rezim Gus Dur isu perburuhan yang hangat saat itu adalah buruh menuntut pembatalan Undang-undang No. 25 Tahun 1997 tentang Ketenagakerjaan, Presiden merangkul buruh dan NGO, isu penerbitan Peraturan Menteri Tenaga Kerja No. 150 Tahun 2000 tentang Penyelesaian Pemutusan Hubungan Kerja dan Penetapan Upah Pesangon, Uang Penghargaan dan Ganti Rugi oleh Perusahaan yang dianggap buruh sebagai titik penting perlindungan hak buruh, lalu Gus Dur konsen sekali terhadap isu perlindungan buruh migran, isu kebebasan mendirikan serikat buruh tapi juga diikuti oleh perpecahan atau fragmentasi di antara serikat buruh.

Terakhir semasaSBY, isu yang berkembang adalah tuntutan kenaikan upah, isu jaminan sosial, BPJS, isu kesetaraan dan keadilan gender, isu kewarganegaraan, isu buruh Go Politic, isu mogok nasional, isu pendirian partai buruh, isu penolakan RUU KAMNAS, isu penolakan RUU ORMAS, dan isu kepemimpinan tunggal buruh, isu fragmentasi serikat buruh karena chauvinisme dan eklusivisme kelompok dan isu lintas sektoral. Jika dilihat dari perkembangan isu tersebut ternyata gerakan buruh mengalami dialektika dan dinamisasi isu yang begitu cepat dan plural tidak hanya masalah isu kenaikan upah saja, bahkan sampai isu lintas sektoral. Artinya melihat gerakan buruh sekarang dengan mendasarkan diri pada perkembangan isunya bisa dikatakan bahwa gerakan buruh di Indonesia sudah sampai fase gerakan New Labour yang tidak hanya berkutat pada masalah upah atau hubungan industrial semata tapi sudah jauh melangkah ke isu-isu yang bersifat politik praktis maupun politik makro.

\section{Daftar Pustaka}

\section{Buku dan Jurnal}

Benington, J. and Donnison, D. (Eds)/1999. 'New Labour and Social Exclusion: the Search for a Third Way - or just Gilding the Ghetto again?', dalam H. Dean and R. Woods(Social Policy Review 11). London: Social Policy Association. 
Cochrane, A.(Eds)/1999. ‘New Labour, New Urban Policy?'. dalam H. Dean and R. Woods(Social Policy Review 11). London: Social Policy Association.

Ebenstein, William.(2006). Isme-Isme Yang Mengguncang Dunia. Yogyakarta : Narasi.

Engel, Frederick. (2007). Tentang Das Capital. Jakarta : Oey Rennesaince.

Fairclough, N. (2000). New Labour, New Language?. London: Routledge.

Faulks, Keith. (2012). Sosiologi Politik: Pengantar Kritis. Jakarta: Nusa Media.

Hadiz, Vedi R. (2005). Dinamika Kekuasaan: Ekonomi Politik Indonesia Pasca-Soeharto. Jakarta: LP3ES.

Held, David.(1980). Introduction to critical theory: Horkheimer to Habermas. University of California Press.

Hidajat, M.S. (2012). Seabad Gerakan Buruh Indonesia. Jakarta: Nuansa Aulia.

Jurnal Sosial Demokrasi. Vol. 10, 4, Edisi Januari-Maret 2011.

Laclau, Ernesto\& Moufee, Chantal. (2008). Hegemoni dan Strategi Sosialis: Post Marxisme dan Gerakan Sosial Baru. Yogyakarta: Resist Book.

Lister, R. (Eds)/2000. 'Gender and the analysis of social policy'. dalam G. Lewis, S. Gewirtz

and J. Clarke(Rethinking Social Policy). London: Sage.

Magnis-Suseno, Franz. (2013). Dari Mao ke Marcuse: Percikan Filsafat Marxis PascaLenin. Jakarta: Gramedia Pustaka Tama.

Patria, Nezar \& Arief, Andi. (2009). Antonio Gramsci: Negara \& Hegemoni, Yogyakarta: Pustaka Pelajar.

Powel, Martin. (1999). New Labour, New Welfare State?. Bristol: Policy Press.

Sayers, Sean. (2007). "The Concept of Labor:Marx and His Critics". Journal Science $\mathcal{E}$ Society, Vol. 71 No. 4 Edisi Oktober.

Tirtosudarmo, Riwanto. (2007). Mencari Indonesia: demografi-politik pasca-Soeharto. Jakarta: LIPI Press.

\section{Media Massa dan Internet}

Harian Kompas, "Buruh Khawatir atas Peningkatan Anggaran Militer", Senin 10 September 2001.

http://id.wikipedia.org/wiki/Upah_minimum_

regional. (diakses 28 Desember 2013).

http://www.marxists.org/indonesia/archive/

lenin/1913/tigasumb.htm. (diakses 30

Desember 2013).

http://ekbis.sindonews.com/read/2013/02/06/

34/714899/ini-alasan-buruh-tolak-ruukamnas-dan-ruu-ormas.

http://www.metrotvnews.com/metronews/ read/2013/11/02/5/191995/16-Perusahaan

Terkena-Dampak-Aksi-Mogok-Nasional

http://www.republika.co.id/berita/nasional/

jabodetabek-nasional/13/10/31/mvj5dc-

buruh-demo-depok-tutup-tiga-jam.

(diakses 7 Januari 2013).

http://www.antaranews.com/berita/401348/

buruh-berencana-gelar-mogok-nasional-

28-30-oktober.

http://nasional.kompas.com/read/2011/07/

13/15490676/Alasan.Serikat.Buruh.Menolak.

RUU.BPJS. (diakses 7 Januari 2013).

https://docs.google.com/document/

d / 1 S 7 Y 0 q C V g K m V W o 5 B r Z

NKiaqE4EEJK8S1BbVq8EwDE_Y/ edit?pli=1. (diakses 7 Januari 2014).

http://www.rmol.co/read/2013/08/01/120510/

Buruh-Di-Cakung-Ngadu-Ke-Kantor-

Komnas-HAM-. (diakses 30 Desember 2013).

http://www.jpnn.com/read/2013/11/22/202132/

Ribuan-Karyawan-Terancam-PHK-.

(diakses 30 Desember 2013).

http://www.tempo.co/read/news/2004/10/11/

05549214/Front-Nasional-Buruh-Tagih-

Janji-SBY. (diakses 30 Desember 2013).

http://indoprogress.blogspot.com/2007/08/

serikat-buruhserikat-pekerja-di.html

http://www.nu.or.id/a,public-m,dinamic-

s,detail-ids,44-id,44169-lang,id-c,nasional

t,Gus+Dur++Pembebas+Gerakan+Buruh- . phpx. (diakses 30 Desember 2013). 
http://www.metrotvnews.com/metronews/ read/2013/11/02/5/191995/16-PerusahaanTerkena-Dampak-Aksi-Mogok-Nasional. (diakses 7 Januari 2014).

http://www.gusdur.net/opini/Detail/?id=195/ hl=id/Pembela_Sejati_Kaum_Buruh_ Migran. (diakses 30 Desember 2013).

http://www.pelita.or.id/baca.php?id=7721. (diakses 9 Januari 2014)

h t t p : // w w w.balipost.co.id / BALIPOSTCETAK/ 2003/3/26/n2.htm. (diakses 9 Januari 2014)

http://www.minihub.org/siarlist/msg03528. html. (diakses 30 Desember 2013)

https:/www.wsws.org/en/articles/1998/05/ pemb-m28.html (diakses 30 Desember 2013).

http://www.elsam.or.id/downloads/ 1326791999_Saepul_Tavip_Nestapa_ Kaum_Buruh.pdf. (diakses 31 Desember 2013). http://www.unisosdem.org/article_detail.php?a $\mathrm{id}=491 \&$ coid=2\&caid=20\&gid=1. (diakses 30 Desember 2013).

http://tyastyfa.blogspot.com/2012/05/masareformasi-indonesia.html. (diakses 30 Desember 2013).

http://www.lancaster.ac.uk/sociology/ research/publications/papers/jessop-fromthatcherism-to-new-labour.pdf. (diakses 30 Desember 2013).

http://www.socialpolicy.ed.ac.uk/_data/assets/ pdf_file/0011/58709/New_Labour_and_ partlic_health.pdf

http://www.boyung.net/docs/Ideology_and_ policy_development_c1_analytical $\% 20$ framework.pdf. (diakses 29 Desember 2013). http://re-searchengines.com/0806edi.html. (diakses 29 Desember 2013).

http://www.rebelion.org/hemeroteca/petras/ english/critique170102.htm. (diakses 7 Mei 2014). 